\title{
ON CAMPUS
}

\section{Reflections on the South African Higher Education Leadership and Management (HELM) First Virtual Summit, 9-11 December 2020: Leadership for a Sustainable and Resilient Higher Education System in an Age of Complexity and Change}

Bernadette J. Johnson ${ }^{\mathrm{i}}$

\section{What is the Purpose of Universities and Higher Education Institutions?}

2020 presented a moment to step back and to think: What just happened? What are we doing? Who are we? Moments of crisis create the opportunity for such reflection. So, for higher education it is: What is our role, what are our purposes?

The pandemic brought home the point that we are vulnerable, we are fragile, we go through trauma and we do not have control all the time, we cannot plan for every eventuality. It is a humbling and a core disruptive experience. It drove home powerfully the idea that we must stick together, we must help one another, we must build our community, and we are not separate from nor above society and humanity. We must anchor ourselves in society and serve society. We have the opportunity to be the beacon of hope for society.

This requires the university to be what society should be. Universities cannot call for inclusion, non-racisms and an end to gender-based violence and then not be sites of what inclusion and safety should look like. The pandemic reality amplified our fractured nature of society. All existing problems of gender based violence, of inequality and poverty worsened and are now perhaps forms of pandemics within the health pandemic. The university needs to be an anchor for society. What are the limits and possibilities of the university being anchored? What can we take responsibility for and what can we not take responsibility for? In which ways are universities an instrument of convergence for society?

If the past and present are not understood how can we project into the future? Unprecedented events have taken place in addition to the pandemic. \#FeesMustFall showed disconnect between university leadership and the university's relation to society. How do we strengthen our connections? What are the possibilities and limits of a university that engages with its society?

Do we understand the political economy of public universities and higher education? The nature of society is changing with the emergence of datarism. How should we respond to these new societal pressures and its focus on technology and data without losing sight of inequality and other societal fractures and contributing to new forms of inequality and fracture?

i Dr Bernadette Judith Johnson is Director: Transformation and Employment Equity at the University of the Witwatersrand, South Africa. Email: bernadette.johnson@wits.ac.za 
Universities have different strengths. We need to think more about what different universities are good for and good at. How do we ensure our sustainability? What kind of leadership is needed? Leadership needs to include thinking about humility, distributed leadership, trust and open mindedness recognising our fragility and the need to know how to work with uncertainty and adaptability. Leadership needs to contribute to healing the fractures in society.

There is a need to have a shared understanding within the sector of resilience, sustainability and what the purpose of the university is. It is no longer adequate that we have different understandings of transformation. What do we mean by transformation? We must give consideration to what has changed in the structure and what changes in the conjunctures. A supportive political economy is needed for transformation across the sector. We cannot anchor the university if municipalities, for example, are falling apart in the local contexts.

The pandemic context has introduced a new language of social distancing and online or digital learning. This too is related to transformation. What is our common understanding? If we do not develop a shared understanding of the role of the university, transformation and decolonisation, we will not know what we must be resilient and sustainable for and therefore we will remain turbulent, fragile, conflict ridden and socially divided. If we do not develop a common understanding, a social contract, how will we know we are transforming?

In setting out the role of the university we need to get clearer on which parts of the university needs competition, which parts need to be protected from competition, and which sections need to be enhanced in relation to collaboration and collective action. How do we balance competition, cooperation, and planning and university autonomy as we build a new social compact? Should we continue to engage and support rankings, for example? What would a social compact look like? We also need to recognise what South Africa has done differently and better, and what in fact the rest of the world can learn from South Africa. The challenges we have now emerge as a consequence of the transformation that has taken place. We have more black students and more black staff in universities. We struggle with institutional culture change and we struggle with black representation in management.

In thinking about our role, we need to pay attention to what we may not be seeing and what we are not talking about enough. What about the commoditisation of private data, the rise of data capitalism and how it is creating a future world. What is the relationship with industry? What is the relationship with private higher education? Our processes of accreditation of new courses take three to four years and by then their relevance is cold. The intensive complexity and concentration of power in technology such as the iPhone (as an example) means that humans are playing catch up. We cannot simply extrapolate from the past in a world that is non-linear and profoundly complex.

We need to consider the role of the university in relation to post-schooling. Universities now see and live the need for greater collaboration. What the university does for society is what it must do for itself. Technology as platforms for interaction is critical and is not a panacea. 
Arriving at a social compact requires a broader social compact in society. How do we arrive at a social compact? In being more online, will all universities become like Unisa? What is the place of blended learning and hybrid models? The same infrastructure will not be needed. Classrooms will look different. The pandemic has opened up the possibility and urgency of different ways of doing teaching and learning and research. It does not only entail acquiring the right technological infrastructures and skills by both staff and students, but it requires beyond emergency online learning and teaching what a digital learning environment looks like. How do staff experience it? How do students experience it? How does this take their needs into account to support a mind shift and mental health embedded in empathy and compassion for the problems people run into and will run into? Campuses must be experienced as caring environments that encourages giving back for life.

How can resources in relation to information, capacity and delivery be shared and re-imagined in a collaborative way both in relation to the digital learning environment and in relation to the programme qualification mix? Significant cost savings will be made and new creative platforms for collaboration and innovation created. In doing so, it will be important to develop a common language of truth so that communication creates a sense of security and shared understanding in complex disruptive contexts.

The conundrum we face is our need for the human connection and how we give space for that within the mix of contact and online engagements. What are the implications for pedagogies as well as the practical learning and assimilations that can be conducted online? The survivalist context has been challenging for staff and students. Staff miss interacting with their students and having human interaction. Online has presented the opportunity for great access by disabled students and a different experience of internationalisation of courses and programmes as well as work and learning experiences.

Retaining empathy, awareness and sensitivity will be important in ensuring that everyone is understanding and participating in the mind set change in ways that keep students at the centre, allow for retention and service back to the university as citizens and alumni. The pandemic raises the need for us to prepare the university for disruptions, agility and flexibility as there will be new future disruptions brought about by, for example, climate change. Vaccination may lead to people pushing for a return to what they regard as normal and familiar, the university as a physical location, and reverse the opportunity for the creation of new flexible, agile and resilient systems. How are we constrained by our imagination of what might be possible? At the same time, what might be lost with reduced physical human interaction? How then do we bounce forward?

What will make universities different? A re-think of the future of higher education is needed perhaps in the same ways in which it was required in 1995 with the National Commission of Higher Education (NCHE). What has worked? What has not worked? Given the new realities the funding model must change. It has not been relevant and remains irrelevant. Should a new Size and Shape for the sector be considered? For example, our cooperative governance structures are not necessarily what we need. What new structures do we need to address our needs? How are we strengthening transdisciplinary research and programmes to address knowledge problems? What is the impact of the university on society? How are we getting the input from industry and civil society to 
advice on our PQM? Which programmes can be shared across institutions and which kept and which dropped? Costing of programmes needs to be enhanced across the system. What can universities focus on in their local context? Critical to focus on is what the system funds, how it funds it, what it teaches and how it teaches. What this means for higher education must be aligned to the importance of Early Childhood Development and the financial sustainability of education as a whole. The funding formula and planning has to be informed by the sustainability of a system which is relevant. We need to take stock deeply of where we are. We need to create more opportunities to research and converse on the future of the system.

The opportunity to step back and rethink requires a leadership who is imaginative and keeps being imaginative. A leadership who continuously reflects on: re-thinking; re-imagination; and re-positioning. A leadership who embraces and engages the need for change and sees the need for a community of practice that continuously engages in processes of re-consideration.

\section{Emerging actions:}

- Research and round table conversation on the political economy of higher education and the implications for university leadership

- Future conference on the social anchoring of the university in society - what would it look like?

- Research on what has changed, is different and the rest of the world can learn from in higher education in South Africa.

- How do we go about developing a social contract which takes into account its societal embeddedness?

\section{Programmatic input into leadership development:}

- What might the future purposes and roles of higher education institutions be?

- What kind of higher education leadership is needed for the anchoring of universities in society?

\section{How to cite:}

Johnson, B.J. (2021). Reflections on the South African Higher Education Leadership and Management (HELM) First Virtual Summit, 9-11 December 2020: Leadership for a Sustainable and Resilient Higher Education System in an Age of Complexity and Change. Journal of Student Affairs in Africa, 9(1), 235-238. DOI: 10.24085/jsaa.v9i1.1442 